\title{
Performance investigation of the drying of parsley in a tray dryer system
}

\section{Ebru Hancioglu}

Geothermal Energy Research and Application Center, Izmir Institute of Technology,

TR-35430 Urla, Izmir, Turkey

E-mail: ebrukuzgunkaya@iyte.edu.tr

\section{Arif Hepbasli*}

Department of Mechanical Engineering,

Ege University,

TR-35100 Izmir, Turkey

E-mail: arif.hepbasli@ege.edu.tr

${ }^{*}$ Corresponding author

\section{Filiz Icier and Zafer Erbay}

Department of Food Engineering,

Ege University,

TR-35100 Izmir, Turkey

E-mail: filiz.icier@ege.edu.tr

E-mail: zafererbay@yahoo.com

\section{Neslihan Colak}

Department of Food Engineering,

Pamukkale University,

TR-20070 Denizli, Turkey

Solar Energy Institute,

Ege University,

TR-35100 Izmir, Turkey

E-mail: neslihan.colak78@gmail.com

\begin{abstract}
The performance of a tray dryer system for the parsley drying process was assessed using energy and exergy analysis methods in this study. The drying temperature ranged from $40^{\circ} \mathrm{C}$ to $60^{\circ} \mathrm{C}$, while the drying air velocity varied from $0.5 \mathrm{~m} / \mathrm{s}$ to $1.5 \mathrm{~m} / \mathrm{s}$. The higher temperature and lower velocity led to higher exergy and energy efficiencies. The exergy efficiency value for the overall system on a product/fuel basis was found to be $3.62 \%$. The values for Specific Moisture Extraction Rate (SMER) and Specific Moisture Exergetic index (SMExR) were obtained to be 0.08 and $2.47 \mathrm{~kg} / \mathrm{kWh}$, respectively.
\end{abstract}


Keywords: drying; exergy analysis; energy analysis; parsley; performance assessment; tray dryer.

Reference to this paper should be made as follows: Hancioglu, E., Hepbasli, A., Icier, F., Erbay, Z. and Colak, N. (2010) 'Performance investigation of the drying of parsley in a tray dryer system', Int. J. Exergy, Vol. 7, No. 2, pp.193-210.

Biographical notes: Ebru Hancioglu is a specialist in the Geothermal Energy Research and Application Center at Izmir Institute of Technology. She received her BSc degree in Chemical Engineering from the Yıldız Technical University, Istanbul, and her MSc and $\mathrm{PhD}$ degrees from the Solar Energy Institute, Ege University, Izmir, Turkey. Some of her research areas include energy and exergy analyses of thermal systems and ground-source heat pumps. She has a certificate in energy management.

Arif Hepbasli is a Full Professor of Mechanical Engineering at Ege University, Izmir, Turkey. Before joining the university in 1996, he worked for 10 years in various Turkish energy companies. Some of his research covers exergy and exergoeconomic analyses of energy systems, energy efficiency and management, and geothermal heat pumps. He is a Certified Energy Manager, and has authored/co-authored more than 340 conference and journal papers. $\mathrm{He}$ has chaired/co-chaired many national and international conferences, symposia, workshops and technical meetings. He has served as a consultant regarding his research area and is a member of the editorial board in various prestigious international journals.

Filiz Icier earned her BS, MS and PhD in Food Engineering, Ege University Turkey. She worked in a food company for two years after graduation. From 1996 to 2005, she was a Research Assistant at the Ege University. By now, she is an Assistant Professor in the same department where she has been Vice President for November 2006-December 2007. She has several cited papers on mathematical modelling, electrical processing, drying, thawing of foods, and rheological, electrical properties of foods, exergy and energy analyses of food systems, optimisation of food processes. She is a member of The Chamber of Food Engineers in Turkey.

Zafer Erbay graduated from the Department of Food Engineering in Ege University in 2006 and received his MSc Degree from the same department and university in 2008. He is pursuing his $\mathrm{PhD}$ in the Food Engineering branch of the Institute of Natural and Applied Sciences in Ege University. He is working in the Department of Food Engineering in Ege University as a research assistant. He pursued studies on drying technology, modelling and optimisation in the food processing, exergy analyses and heat pump applications in food processes.

Neslihan Colak graduated from the Department of Food Engineering in Pamukkale University in 1999 and received her MSc Degree from the same department and university in 2002. She received her PhD in the Solar Energy Institute at the Ege University. She is working in the Department of Food Engineering in Pamukkale University as a Research Assistant. Some of her research areas include energy and exergy analyses of thermal systems, evaporation and drying technology and renewable energy sources applications in food engineering processes. 


\section{Introduction}

Parsley (Petroselinum crispum Mill.) is a widely used culinary, medicinal and aromatic plant. The fresh or dried leaves, roots and seeds of this plant are used in the food, cosmetic and pharmaceutical industries to produce spice, essential oils and drugs. In food preparation, fresh parsley leaves are also used as a garnish and for seasoning. Dried leaves, known as parsley flakes, are particularly used in the instant food sector as an ingredient for flavouring in soups and sausages. Both seeds and leaves are used to produce an essential oil for use in perfumes, soaps, crèmes and seasonings. It is a very rich source of Vitamins $\mathrm{C}$ and $\mathrm{E}, \beta$-carotene, thiamin, riboflavin and organic minerals (Soysal, 2004).

Drying is one of the oldest unit operations and has recently become widespread in various industries. It has been used in different industries to gain different utilities. The methods of drying are diversified according to the purpose of the process. There are more than 200 types of dryers (Mujumdar, 1997). For every dryer, the process conditions, such as drying chamber temperature, pressure, air velocity (if the carrier gas is air), relative humidity and product retention time have to be determined according to feed, product, purpose and method. On the other hand, drying is an energy-intensive process and its energy consumption value is $10-15 \%$ of the total energy consumption in all industries in developed countries (Keey, 1972; Mujumdar, 1997). In brief, drying is arguably the oldest, most common, most diverse, and most energy-intensive unit operation, and because of all these features, the engineering in drying processes gains in importance (Erbay and Icier, 2009).

Exergy analysis is a very useful tool, which can be successfully used in the design of an energy system and provides useful information to choose the appropriate component design and the operation procedure. This information is effective in determining the plant and the operation cost, the energy conservation, the fuel versatility and the pollution. In recent years, exergy analysis has been widely used for the performance evaluation of thermal systems. Although the energy analysis method has been widely used in evaluating the performance of food systems, studies on exergy analysis, especially on exergetic assessment of drying process, are relatively few in number (Midilli and Kucuk, 2003; Dincer and Sahin, 2004; Akpinar, 2004; Akpinar et al., 2005a, 2006b). In these studies, the drying process was thermodynamically modelled by Dincer and Sahin (2004), while drying of different products, such as wheat kernel (Syahrul et al., 2003), pistachio (Midilli and Kucuk, 2003), red pepper slices (Akpinar, 2004), potato (Akpinar et al., 2005a), apple slices (Akpinar et al., 2005b) and pumpkin (Akpinar et al., 2006b), laurel leaves (Kuzgunkaya and Hepbasli, 2007a, 2007b), pasta (Ozgener, 2007), green olive (Colak and Hepbasli, 2007), mint (Colak et al., 2008), was evaluated in terms of energetic and exergetic aspects using various drying devices, such as fluidised bed dryers, solar assisted dryers, convective type hot-air dryers and heat pump dryers.

Although open sun drying, convective drying and microwave drying behaviours of parsley were investigated and modelled (Soysal, 2004; Akpinar et al., 2006a; Doymaz et al., 2006; Soysal et al., 2006; Gornicki and Kaleta, 2007) and some drying quality features of parsley such as colour qualities, rehydration ratios, microbial loads, were discussed (Bobic et al., 2002; Doymaz et al., 2006; Yaghmaee and Durance, 2007), there has been no study on the performance of drying of parsley and/or drying systems used in parsley drying to the best of the authors' knowledge. The main objectives of this paper are as follows: 
- to perform an energy and exergy analysis during tray drying of parsley under different operating conditions

- to investigate the effects of the inlet drying air temperature and the velocity on both energy and exergy efficiencies

- to discuss the performance and improvements in the drying system.

\section{Materials and method}

\subsection{Material}

Fresh parsley (Petroselinum crispum Mill.) was purchased from a local market in Izmir, Turkey. The purchased parsley was washed with water and then the excess water on the surface of the parsley was removed with a filter paper. The purchased parsley was processed within $24 \mathrm{~h}$.

\subsection{Method}

\subsubsection{Experimental set up}

Parsley was dried in a laboratory type tray dryer (Armfield UOP8, Hampshire, UK) shown schematically in Figure 1.

Figure 1 Schematic illustration of the tray drier used

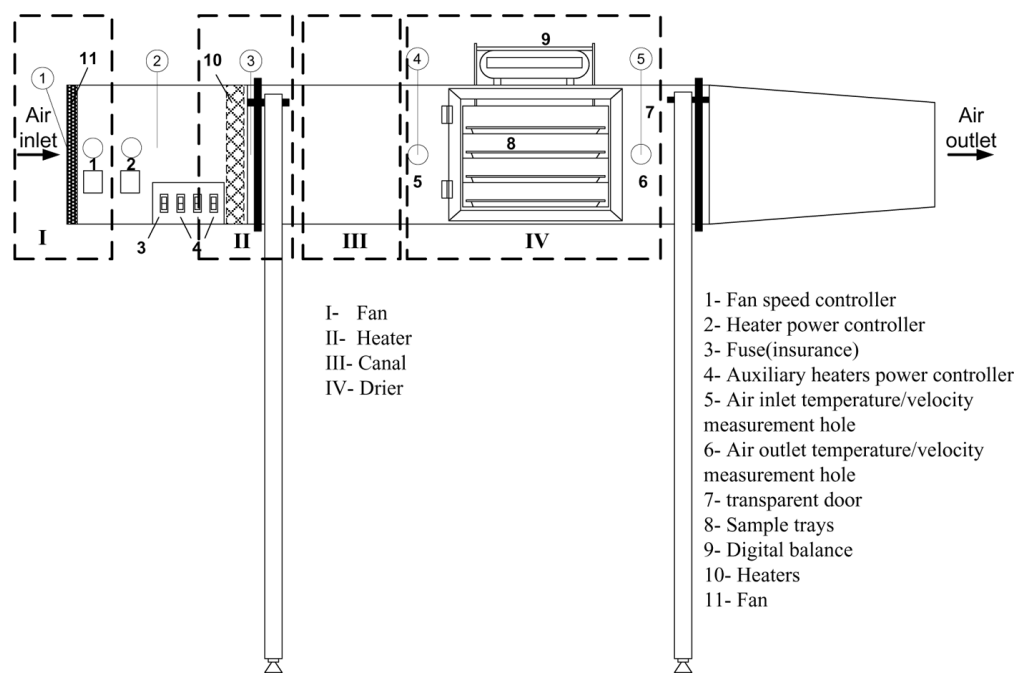

In the tray dryer, the drying air velocity was adjusted by an axial flow fan and fan speed control unit. The air was heated with an electric $3 \mathrm{~kW}$ heater placed inside the duck and air temperature was controlled by a heater power control unit. The dimensions of the drying compartment were $0.3 \times 0.3 \times 0.4 \mathrm{~m}$. The dryer included four sample trays. 


\subsubsection{Drying procedure and measurements}

Parsley was spread onto the trays as a thin layer and drying experiments were carried out at drying air velocities of $0.5,1.0$ or $1.5 \mathrm{~m} / \mathrm{s}$ in the tray dryer. The drying temperatures were 40,50 or $60^{\circ} \mathrm{C}$.

Humidities, temperatures and velocities were measured with robust humidity probes (Testo, 0636.2140, Freiburg, Germany), vane/temperature probes (Testo, 0635.9540, Freiburg, Germany) and a professional telescopic handle for plug-in vane probes (Testo, 0430.0941, Freiburg, Germany), respectively. Measurements of drying air temperature, velocity and relative humidity were recorded at the inlet and outlet holes at every $10 \mathrm{~min}$ for the tray dryer. The surface temperature of the equipment was measured with a digital multimeter (Metex ME-32, Seoul, Korea) and the surface temperature of the parsley during the drying was measured with an infrared thermometer with a laser sighting (Testo 525-T2, Freiburg, Germany). A digital balance (Scaltec SBA 61, Goettingen, Germany) was used to measure the weight loss of the sample during the drying experiments. The ambient temperature and the relative humidity were observed and recorded with a multi-function instrument (Testo 350-XL/454, Control unit, Freiburg, Germany).

The moisture content in the sample was determined using the vacuum-oven method (AOAC, 1990). The protein, ash, fat, carbohydrate and fibre contents of the parsley were determined (IUPAC, 1987; AOAC, 1995a, 1995b; TSE, 2003) (Table 1), while $C_{p}$ was calculated from equation (1);

$$
C_{p}=C_{\text {prot }} X_{\text {prot }}+C_{\text {fat }} X_{\text {fat }}+C_{\text {carb }} X_{\text {carb }}+C_{\text {ash }} X_{\text {ash }}+C_{\text {fibre }} X_{\text {fibre }}+C_{w} X_{w} .
$$

Table 1 The composition of parsley dried in this study

\begin{tabular}{lc}
\hline Content & $\%$ \\
\hline Water & 83.4 \\
Protein & 3.0 \\
Carbohydrate & 8.5 \\
Fat & 0.8 \\
Fibre & 3.3 \\
Ash & 1.0 \\
\hline
\end{tabular}

\subsubsection{Experimental uncertainty}

Uncertainty analysis is needed to prove the accuracy of the experiments. Errors and uncertainties in the experiments can arise from the instrument selection, condition, calibration, environment, observation and reading, and test planning (Akpinar et al., 2003). An uncertainty analysis was performed using the method described by (Holman, 2001):

$$
U_{F}=\left[\left(\frac{\partial F}{\partial z_{1}} u_{1}\right)^{2}+\left(\frac{\partial F}{\partial z_{2}} u_{2}\right)^{2}+\cdots+\left(\frac{\partial F}{\partial z_{n}} u_{n}\right)^{2}\right]^{1 / 2}
$$




\section{Modelling and analysis}

Mass, energy and exergy balances were employed to find the heat inputs, the rates of exergy destructions, and energy and energy efficiencies. Steady-state, steady-flow processes are assumed. A general mass balance was expressed in rate form as

$$
\dot{m}_{\text {in }}=\dot{m}_{\text {out }}
$$

where $\dot{m}$ was the mass flow rate, and the sub-script 'in' stands for inlet and 'out' for outlet.

Energy and exergy balances, equating total energy (exergy) inputs to total energy (exergy) outputs, were written as

$$
\begin{aligned}
& \dot{E}_{\text {in }}=\dot{E}_{\text {out }} \\
& \dot{E} x_{\text {in }}-\dot{E} x_{\text {out }}=\dot{E} x_{\text {dest }} .
\end{aligned}
$$

The specific flow exergy of refrigerant, air or water was evaluated as

$$
\psi_{r, w}=\left(h-h_{0}\right)-T_{0}\left(s-s_{0}\right) .
$$

The enthalpy and entropy of air were calculated from the following equations, respectively (Schmidt et al., 1998)

$$
\begin{aligned}
& h=C_{p} T+\omega h_{f g} \\
& s=C_{p_{\text {,air }}} \ln \frac{T}{T_{0}}-R_{\text {air }} \ln \frac{P_{0}-R H \cdot P^{\prime}}{P_{0}}+\omega\left(s^{\prime}-R_{w} \ln R H\right) .
\end{aligned}
$$

The exergy rate was determined as

$$
\dot{E} x=\dot{m} \psi
$$

where $h$ was the enthalpy, $s$ was the entropy, and the sub-script zero indicated properties at the dead (reference) state (i.e., at $P_{0}$ and $T_{0}$ ).

The specific moisture extraction rate was defined as the ratio of the moisture removed, in $\mathrm{kg}$, to the energy input in $\mathrm{kWh}$ (Hawlader and Jahangeer, 2006):

$$
\begin{aligned}
& S M E R=\frac{\text { Moisture removed in } \mathrm{kg}}{\text { Energy input in } \mathrm{kWh}} \\
& S M E R=\frac{\dot{m}_{w}}{\dot{W}_{\text {heater,elec }}+\dot{W}_{\text {fans,elec }}}
\end{aligned}
$$

where $\dot{m}_{w}$ was the moisture in $\mathrm{kg}$ water per hour. Here,

$$
\begin{aligned}
& \dot{W}_{\text {heater,elec }}=\dot{W}_{\text {heater }} / \eta_{\text {heater, elec }} \\
& \dot{W}_{\text {fans,elec }}=\dot{W}_{\text {fans }} /\left(\eta_{\text {fan,elec }} \eta_{\text {fan,mech }}\right) \\
& \dot{W}_{\text {heater,elec }}=\sqrt{3} V_{\text {comp }} I_{\text {comp }} \operatorname{Cos} \varphi
\end{aligned}
$$




$$
\begin{aligned}
& \dot{W}_{\text {fan,elec }}=V_{\text {fan }} I_{\text {fan }} \operatorname{Cos} \varphi . \\
& S M E x R=\frac{\text { Moisture removed in } \mathrm{kg}}{\text { Exergy input in } \mathrm{kWh}}
\end{aligned}
$$

which was defined by Kuzgunkaya and Hepbasli (2007a) for the first time as the ratio of the moisture removed, in $\mathrm{kg}$, to the exergy input, in $\mathrm{kWh}$, and indicated the effectiveness of the exergy input in the drying process

$$
S M E x R=\frac{\dot{m}_{w}}{E \dot{x}_{d a, \text { in }}} .
$$

The energy efficiency of the dryer cabinet was derived by using the energy balance equation. The thermal efficiency of the drying process was defined as (Syahrul et al., 2002):

$$
\begin{aligned}
& \eta=\frac{\text { Energy transmitted to the solid }}{\text { Energy incorporated in the drying air }} \\
& \eta=\frac{W_{d}\left\lfloor h_{f g}\left(M_{p, \text { in }}-M_{p, \text { out }}\right)+c_{m}\left(T_{m, \text { out }}-T_{m, \text { in }}\right)\right\rfloor}{m_{d a}\left(h_{\text {in }}-h_{0}\right) \Delta t} .
\end{aligned}
$$

The exergy balance for the drying cabinet was developed by combining the energy balance and the entropy balance. Multiplying the entropy balance by $T_{0}$ and subtracting the resulting expression from the physical exergy balance gave:

$$
\dot{E} x_{p, \text { out }}-\dot{E} x_{p, \text { in }}=\dot{E} x_{d a, \text { in }}-\dot{E} x_{d a, \text { out }}+\dot{E} x_{\text {evap }}-\dot{E} x_{\text {loss }}-\dot{E} x_{\text {dest }} \text {. }
$$

The exergy efficiency of the dryer cabinet, based on the Second Law of Thermodynamics, was derived using the exergy rate balance equation. The exergy efficiency provided a true measure of the performance of the drying system from the thermodynamic viewpoint. In defining the exergy efficiency it was necessary to identify both the product and the fuel. In this study, the product was the rate of exergy evaporation $\left(E x_{\text {evap }}\right)$, and the fuel was the rate of exergy drying air entering the dryer cabinet $\left(E x_{\mathrm{da} 1}\right)$. The exergy efficiency, on the basis of the exergy rate balance, was given as (Syahrul et al., 2002).

$$
\varepsilon=\frac{\dot{E} x_{\text {evap }}}{\dot{E} x_{d a, \text { in }}} .
$$

The rate of exergy transfer due to evaporation in the dryer was:

$$
\dot{E} x_{\text {evap }}=\left(1-\frac{T_{0}}{T_{a v}}\right) m_{w} h_{f g}
$$

where $\dot{m}_{w}$ was the moisture in $\mathrm{kg}$ water per hour.

The following equation was used to calculate the rate of exergy loss to the surroundings, where $T_{b}$ is the boundary temperature. 


$$
\dot{E} x_{\text {loss }}=\left(1-\frac{T_{0}}{T_{b}}\right) \dot{Q}_{\text {loss }}
$$

The exergy efficiency of the overall system was expressed as the ratio of total exergy output to total exergy input:

$$
\mathcal{E}=\frac{\dot{E} x_{\text {out }}}{\dot{E} x_{\text {in }}}
$$

where 'output' refers to 'net output', 'product', 'benefit' or 'desired value', and 'input' refers to 'driving input' or 'fuel'.

Van Gool's (1997) improvement potential on a rate basis, denoted $I \dot{P}$, was expressed as

$$
I \dot{P}=(1-\varepsilon)\left(\dot{E} x_{\text {in }}-\dot{E} x_{\text {out }}\right) .
$$

Since the initial moisture content of the parsley used in the experiment under various inlet air conditions may be variable, a comparison of drying time and efficiency in terms of absolute moisture content might be misleading. Therefore, normalised moisture was calculated by dividing the moisture of the parsley to moisture of the raw parsley (equation (21));

$$
\text { Normalised moisture }=\frac{M p}{M p_{i}} .
$$

In this study, the dead (reference) state was taken to be the state of the environment at which the temperature and the atmospheric pressure were $14.7^{\circ} \mathrm{C}$ and $101.325 \mathrm{kPa}$, respectively. The thermodynamic properties of water and air were found using the Engineering Equation Solver (F-Chart Software, 2008) software package.

\section{Results and discussion}

Uncertainty analysis was necessary to prove the accuracy of the experiments. The temperature, air velocity, relative humidity and mass losses were measured with appropriate instruments. Uncertainties of the experimental measurements and total uncertainties for predicted values were listed in Table 2. It was obtained that uncertainties were within an acceptable range.

Table 2 Uncertainties of the experimental measurements and total uncertainties for predicted values

\begin{tabular}{lcl}
\hline Parameter & Unit & Comment \\
\hline Experimental measurements & & \\
Uncertainty in the temperature measurement & ${ }^{\circ} \mathrm{C}$ & \pm 0.224 \\
Uncertainty in the weight measurement & $\mathrm{g}$ & \pm 0.00051 \\
Uncertainty in the air velocity measurement & $\mathrm{m} / \mathrm{s}$ & \pm 0.21 \\
Uncertainty in the measurement of relative humidity of air & $\%$ & \pm 0.41 \\
Uncertainty in the surface temperature measurement & ${ }^{\circ} \mathrm{C}$ & \pm 1.0 \\
\hline
\end{tabular}


Table 2 Uncertainties of the experimental measurements and total uncertainties for predicted values (continued)

\begin{tabular}{lcc}
\hline Parameter & Unit & Comment \\
\hline Predicted values & & \\
Total uncertainty for specific heat of parsley & $\mathrm{kJ} / \mathrm{kg}^{\circ} \mathrm{C}$ & $\pm 0.44 \%^{\mathrm{a}}$ \\
Total uncertainty for $\dot{E} x_{\text {in }}$ & $\mathrm{kW}$ & $\pm 1.13 \%^{\mathrm{b}}$ \\
Total uncertainty for $\dot{E} x_{\text {out }}$ & $\mathrm{kW}$ & $\pm 1.29 \%^{\mathrm{c}}$ \\
Total uncertainty for $\dot{E} x_{\text {loss }}$ & $\mathrm{kW}$ & $\pm 0.33 \%{ }^{\mathrm{d}}$ \\
Total uncertainty for $\varepsilon$ & Dimensionless & $\pm 2.20 \%{ }^{\mathrm{e}}$ \\
\hline
\end{tabular}

${ }^{\mathrm{a}}$ Nominal value was taken as 1.826 .

${ }^{\mathrm{b}}$ Nominal value was taken as 0.245 .

${ }^{\mathrm{c} N o m i n a l ~ v a l u e ~ w a s ~ t a k e n ~ a s ~} 0.191$.

${ }^{\mathrm{d}}$ Nominal value was taken as 0.010 .

${ }^{\mathrm{e}}$ Nominal value was taken as 77.93 .

\subsection{Exergetic analysis of parsley drying unit}

The exergy of drying air inflow ( $\left.E x_{\mathrm{da}, \text { in }}\right)$ was higher than the outflow $\left(E x_{\mathrm{da}, \text { out }}\right)$, because of the heat losses and destructions during the drying process (Figure 2). In this study, approximately $26 \%$ of the drying air that entered the drying cabinet has been lost and thus showed the importance of the system's isolation for drying processes.

Figure 2 The change of exergy of drying air entering and existing the dryer with drying time

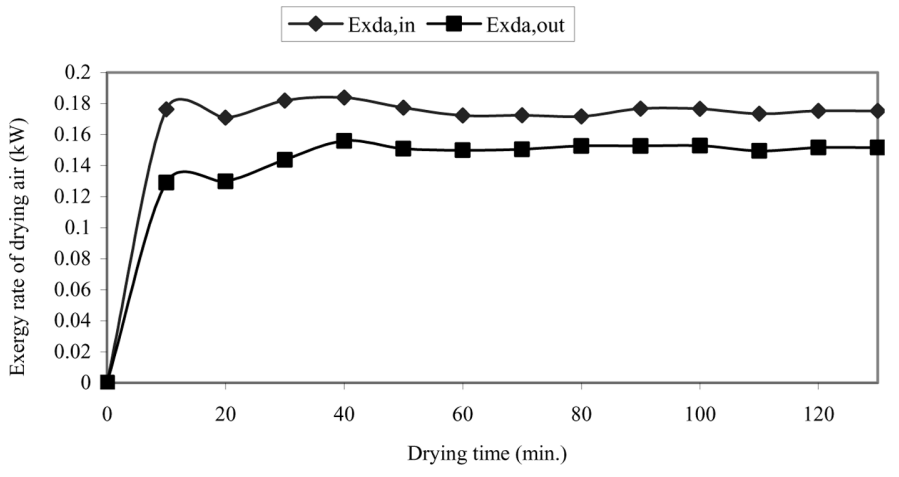

Although biological materials such as agricultural products have a high moisture content, generally, no constant rate period is seen in drying processes (Erbay and Icier, 2009). Figure 3 illustrates the variation of the exergy of evaporation of the tray dryer of the parsley. The exergy of evaporation increased at the initial stages due to the rapid evaporation of the surface moisture, while the exergy rate of evaporation decreased exponentially as the surface moisture evaporated until the end of the drying process. The range of moisture content varied from an initial value of $M_{p i}=0.83$ to a final moisture content of $M_{p f}=0.11$ (Figure 4). The exergy efficiency was found to be higher at the initial stage of the drying process, but decreased exponentially during 
the drying process. The improvement in potential rate was high at the initial stages. It was then nearly constant after $80 \mathrm{~min}$ (Figure 5). The variation of SMER and SMExR during the drying process is given in Figure 6. SMER and SMExR values were higher at the initial stage of the drying process due to the high amount of the moisture removal. As the drying continued and the amount of moisture content removed decreased, the specific moisture extraction rates decreased.

Figure 3 The change of exergy of evaporation with drying time

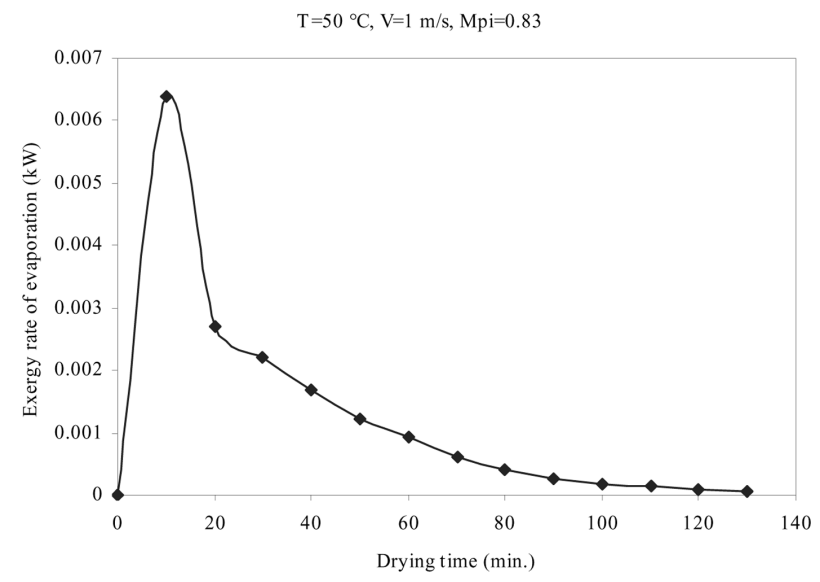

Figure 4 The variation of the exergy efficiency with drying time

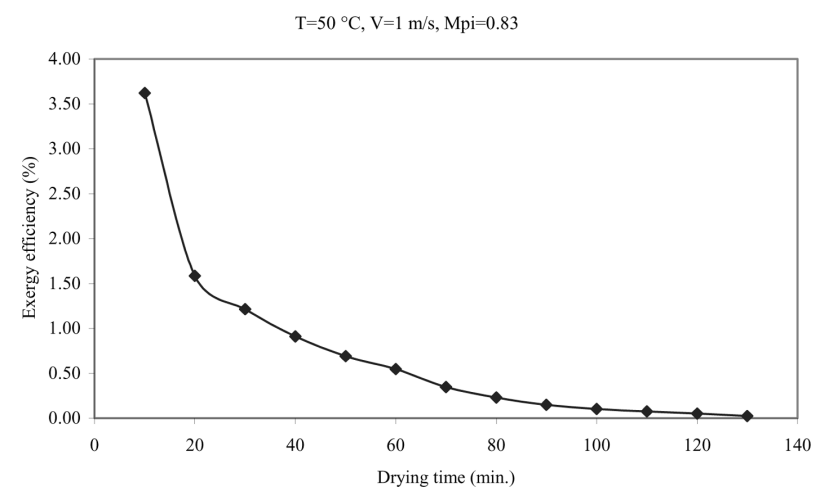

Figure 5 The variation of the improvement potential during drying

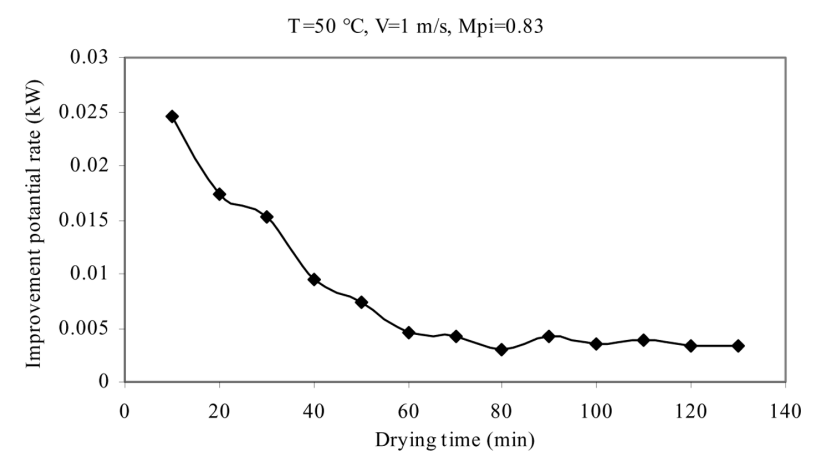


Figure 6 The variation of the SMER and SMExR with drying time

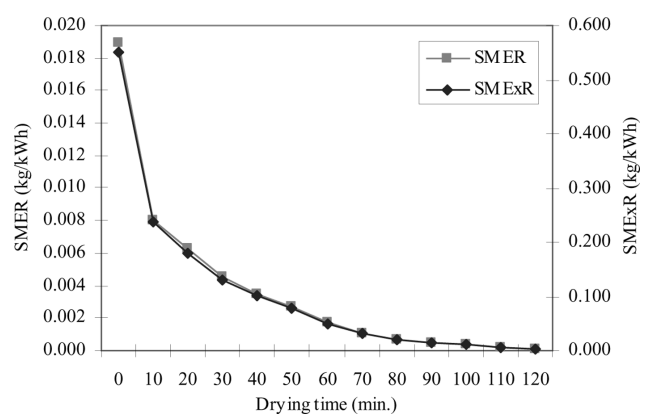

\subsubsection{Effect of temperature on energy and exergy efficiencies}

The drying rate of parsley in thin layer drying was influenced mainly by the drying air temperature $(p<0.05)$ (Figure 7$)$. To compare the efficiency changes for performance evaluation, energy and exergy efficiencies were determined. The energy efficiencies were found to be higher than the exergy efficiencies (Figure 8). As the temperature increased, the enthalpy of the drying air for the same period of time increased. These differences at the initial stage of drying were higher than those at the final stage. Similarly, the entropy of drying air also increased with the temperature, leading to higher energy and exergy efficiencies (Figures 7 and 8). The final temperature of the material after a long time interval became almost equal to the temperature of the inlet drying air.

Figure 7 Effect of inlet air temperature on the Normalised moisture content during drying (at a constant air velocity of $1 \mathrm{~m} / \mathrm{s}$ )

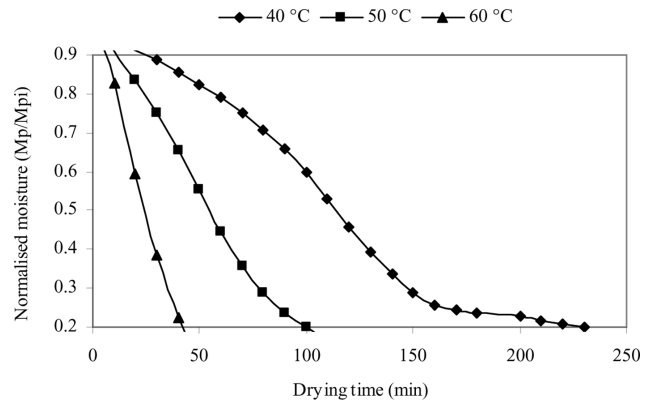

Figure 8 Effect of inlet air temperature on efficiencies depending on normalised moisture content (at a constant air velocity of $1 \mathrm{~m} / \mathrm{s}$ )

$$
\begin{aligned}
& \longrightarrow \text { Exergy Eff: } \mathrm{T}=40^{\circ} \mathrm{C} \longrightarrow \text { Exergy Eff: } \mathrm{T}=50^{\circ} \mathrm{C} \longrightarrow \text { - Exergy Eff; } \mathrm{T}=60^{\circ} \mathrm{C} \\
& \longrightarrow \text { Energy Eff; } \mathrm{T}=40^{\circ} \mathrm{C} \longrightarrow \text { Energy Eff; } \mathrm{T}=50^{\circ} \mathrm{C} \longrightarrow \text { Energy Eff; } \mathrm{T}=60^{\circ} \mathrm{C}
\end{aligned}
$$

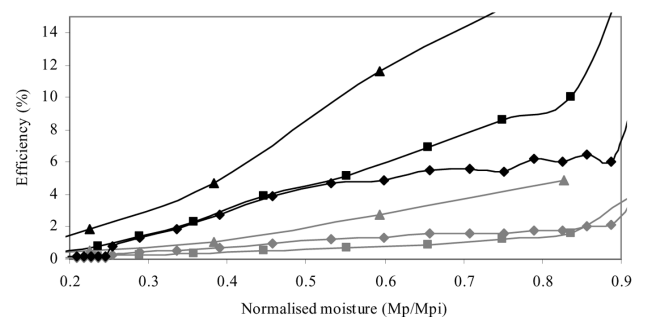




\subsubsection{Effect of air velocity on energy and exergy efficiencies}

Figures 9 and 10 illustrate the effect of air velocity on the drying time and the efficiency of the drying, respectively. The drying rate did not change much due to variations in drying air velocity, so the drying air velocity did not seem to be an important process parameter in parsley drying (Figure 9). However, increasing the drying rate caused a decrease in the energetic and exergetic efficiencies of the drying process (Figure 10). Finally, it was concluded that parsley should be dried with low velocities from the energetic, economic and environmental points of view.

Figure 9 Effect of air velocity on the normalised moisture content during drying of parsley (at a constant drying temperature of $50^{\circ} \mathrm{C}$ )

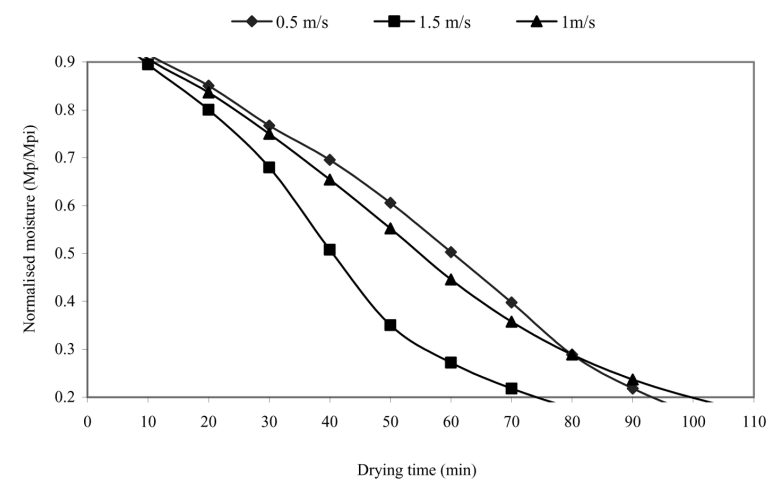

Figure 10 Effect of air velocity on efficiencies depending on the normalised moisture content (at a constant drying temperature of $50^{\circ} \mathrm{C}$ )

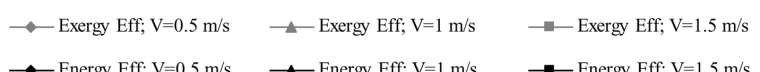

$\longrightarrow$ Energy Eff; $\mathrm{V}=0.5 \mathrm{~m} / \mathrm{s} \quad \neg$ Energy Eff; $\mathrm{V}=1 \mathrm{~m} / \mathrm{s} \quad \longrightarrow$ Energy Eff; $\mathrm{V}=1.5 \mathrm{~m} / \mathrm{s}$

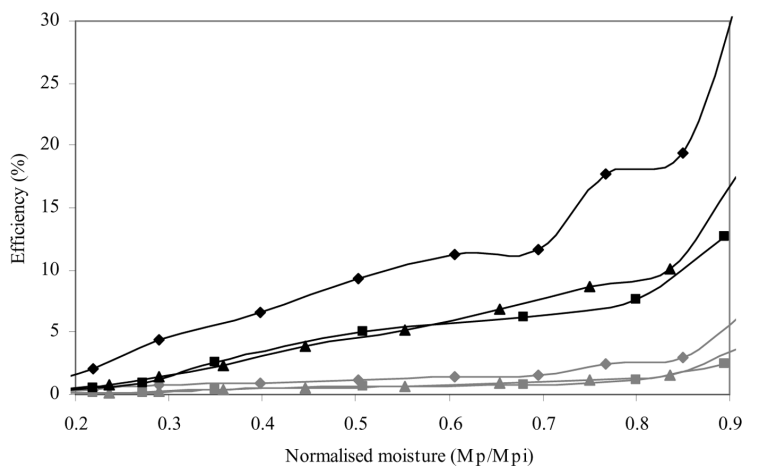

\subsection{Exergetic analysis of the tray dryer system}

The temperature, the pressure and the mass flow rate data for product and air during drying are given in Table 3, following the state numbers specified in Figure 1. By using the exergy rate data given in Table 3, the exergy efficiency values for the overall drying system on a product/fuel basis were estimated to be $3.6 \%$ (Table 4). By comparison with the product/fuel basis of some investigators, Syahrul et al. $(2002,2003)$ reported that exergy efficiency values for corn drying ranged from $2 \%$ to $16 \%$, while exergy efficiency 
values for red-spring wheat drying in a fluidised bed dryer varied between $2-12 \%$, on the basis of product/fuel. Kuzgunkaya and Hepbasli (2007a) found values of 9.11-15.48\% in a ground source heat pump where laurel leaves were dried. In this study, the exergy efficiency for the tray dryer system on a product/fuel basis was 3.6\%.

Table 3 Some thermodynamic data, energy and exergy rates provided for one representative unit of the drying system

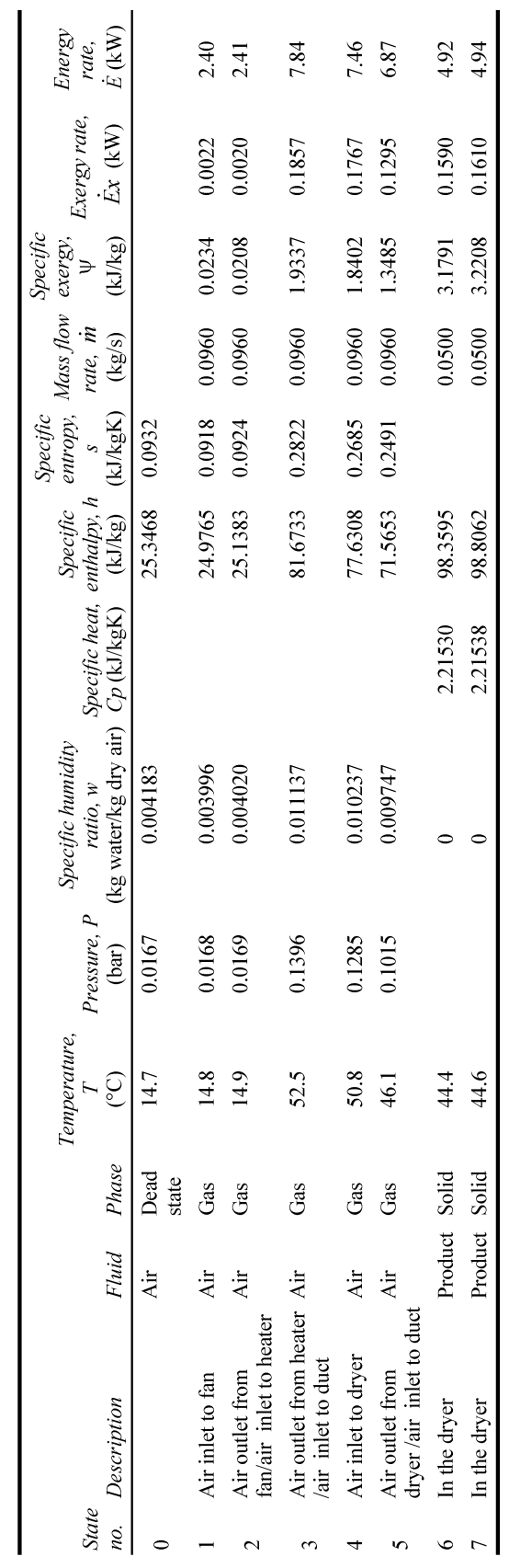


Table 4 Some energetic and exergetic analysis data provided for the drying system $\left(T_{0}=14.7^{\circ} \mathrm{C}\right.$ and $P_{0}=101.325 \mathrm{kPa}$, for $T=50^{\circ} \mathrm{C}$ and $\left.V=1 \mathrm{~m} / \mathrm{s}\right)$

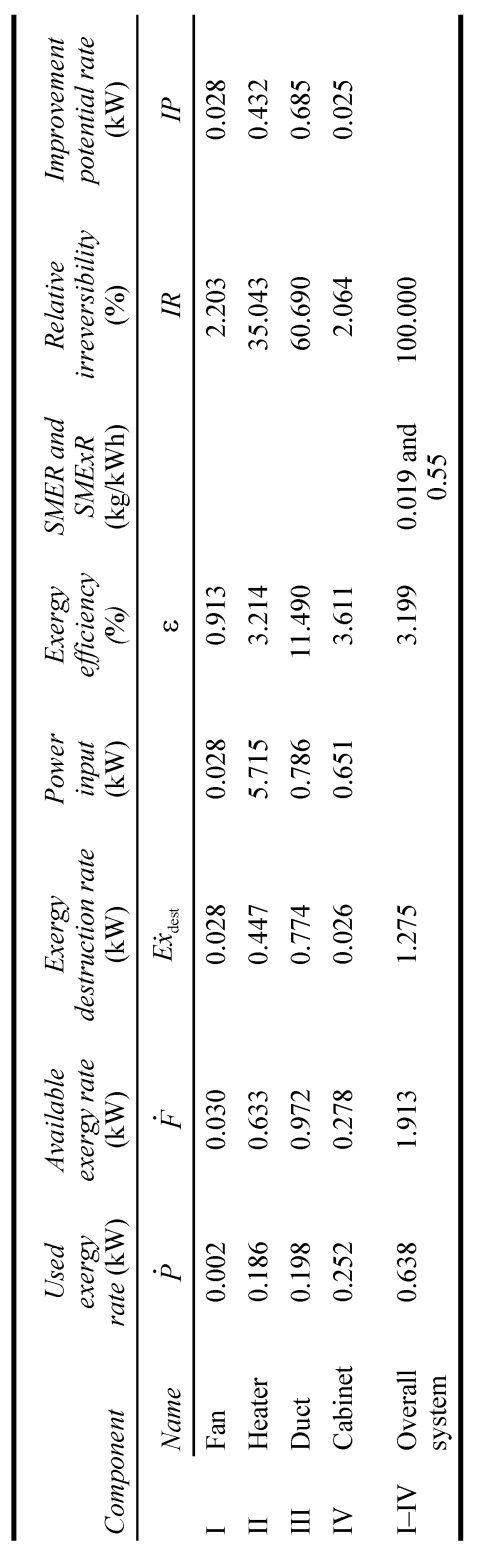

The SMER and SMExR values were found to be 0.019 and $0.55 \mathrm{~kg} / \mathrm{kWh}$ for the drying system. These values showed that the exergy input was more effective in the performance evaluation of the drying process.

The greatest Improvement Potential rate $(I P)$ value was obtained in the drying duct, followed by the heater, fan and drying cabinet. The $I P$ value of the drying duct was calculated to be $0.685 \mathrm{~kW}$ and this indicated the importance of the insulation for the drying processes. Furthermore, the drying cabinet should be designed to dry more products for gaining more utility. So it was important to emphasise the need for paying 
close attention to the selection of this equipment, since components of inferior performance could considerably reduce the overall system performance. The $R I$ value of the drying duct was obtained as $60.69 \%$.

\section{Conclusions}

The main conclusions drawn from the results of the present study may be listed as follows:

- The drying rate of parsley in thin layer drying was influenced mainly by the drying air temperature

- Higher temperature and lower velocity led to higher exergy and energy efficiencies during drying of parsley in the tray dryer system

- The values for SMER and SMExR at a dead state temperature of $14.7^{\circ} \mathrm{C}$, a drying temperature of $50^{\circ} \mathrm{C}$ and an air velocity of $1 \mathrm{~m} / \mathrm{s}$ were found to be 0.019 and $0.55 \mathrm{~kg} / \mathrm{kWh}$, respectively

- The exergy efficiency values for the tray dryer system on a product/fuel basis was $3.6 \%$ at a dead state temperature of $14.7^{\circ} \mathrm{C}$ for the drying temperature of $50^{\circ} \mathrm{C}$ and air velocity of $1 \mathrm{~m} / \mathrm{s}$

- The largest irreversibility in the tray drying system was associated with the duct, followed by the heater

- The results can focus an engineer's attention on components where the greatest potential was destroyed and quantify the extent to which modification of one component affects, favourably or unfavourably, the performance of other components of the system.

\section{Acknowledgements}

The authors are grateful for the financial support provided for the project entitled "Design, test and performance evaluation of a gas engine driven solar assisted band conveyor heat pump drying system" under project no: 106M482 by The Scientific and Technological Research Council of Turkey (TUBITAK). They are also grateful to the reviewers for the valuable comments, which have been utilised to improve the quality of the paper.

\section{References}

Akpinar, E.K. (2004) 'Energy and exergy analyses of drying of red pepper slices in a convective type dryer', International Communications in Heat and Mass Transfer, Vol. 31, No. 8, pp.1165-1176.

Akpinar, E.K., Bicer, Y. and Midilli, A. (2003) 'Modelling and experimental study on drying of apple slices in a convective cyclone dryer', Journal of Food Process Engineering, Vol. 26, pp.515-541. 
Akpinar, E.K., Midilli, A. and Bicer, Y. (2005a) 'Energy and exergy of potato drying process via cyclone type dryer', Energy Conversion and Management, Vol. 46, Nos. 15-16, pp.2530-2552.

Akpinar, E.K., Midilli, A. and Bicer, Y. (2005b) 'Thermodynamic analysis of the apple drying process', Proc. IMechE Part E: J. Process Mechanical Engineering, Vol. 219, pp.1-14.

Akpinar, E.K., Bicer, Y. and Cetinkaya, F. (2006a) 'Modelling of thin layer drying of parsley leaves in a convective dryer and under open sun', Journal of Food Engineering, Vol. 75, pp.308-315.

Akpinar, E.K., Midilli, A. and Bicer, Y. (2006b) 'The first and second law analyses of thermodynamic of pumpkin drying process', Journal of Food Engineering, Vol. 72, No. 4, pp.320-331.

TSE (2003) TS ISO 15598 Çay-Ham Lif İçeriğinin Tayini, Tea-Determination of Crude Fiber Content, Turkish Standards Institution, Ankara, Turkey.

AOAC (1990) 'Dry matter content', in Helrich, K. (Ed.): Official Methods of Analysis of the Association of Official Analytical Chemists, Method No. 920.151, A.O.A.C, Inc., USA.

AOAC (1995a) 'Nitrogen in spices', in Helrich, K. (Ed.): Official Methods of Analysis of the Association of Official Analytical Chemists, 16th ed., Method No. 920.165, A.O.A.C, Inc., USA.

AOAC (1995b) 'Ash of canned vegetables', in Helrich, K. (Ed.): Official Methods of Analysis of the Association of Official Analytical Chemists, 16th ed., Method No. 925.051, A.O.A.C, Inc., USA.

Bobic, Z., Bauman, I. and Curic, D. (2002) 'Rehydration ratio of fluid bed-dried vegetables', Sadhana, Vol. 27, No. 3, pp.365-374.

Colak, N. and Hepbasli, A. (2007) 'Performance analysis of drying of green olive in a tray dryer', Journal of Food Engineering, Vol. 20, pp.1188-1193.

Colak, N., Kuzgunkaya, E. and Hepbasli, A. (2008) 'Exergetic assessment of drying of mint leaves in a heat pump dryer', Journal of Food Process Engineering, Vol. 31, pp.281-298.

Dincer, I. and Sahin, A.Z. (2004) 'A new model for thermodynamic analysis of a drying process', International Journal of Heat and Mass Transfer, Vol. 47, pp.645-652.

Doymaz, I., Tugrul, N. and Pala, M. (2006) 'Drying characteristics of dill and parsley leaves', Journal of Food Engineering, Vol. 77, pp.559-565.

Erbay, Z. and Icier, F. (2009) 'A review of thin layer drying of foods: theory, modeling and experimental results', Critical Reviews in Food Science and Nutrition (in press).

F-Chart Software (2008) Engineering Equation Solver (EES), Version 8.156D, Madison, WI, USA.

Gornicki, K. and Kaleta, A. (2007) 'Modelling convection drying of blanched parsley root slices', Biosystems Engineering, Vol. 97, pp.51-59.

Hawlader, M.N.A. and Jahangeer, K.A. (2006) 'Solar heat pump drying and water heating in the tropics', Solar Energy, Vol. 80, pp.492-499.

Holman, J.P. (Ed.) (2001) 'Analysis of experimental data', Experimental Methods for Engineers, 7th ed., McGraw-Hill, Singapore, pp.48-143.

IUPAC (1987) 'International union of pure and applied chemistry', in Paquot, C. and Hautfenne, A. (Eds.): Standard Methods for the Analysis of Oils, Fats and Derivatives, 7th ed., Blackwell Publications, Oxford, England, method no: 1.122, p.347.

Keey, R.B. (Ed.) (1972) 'Introduction', Drying Principles and Practice, Pergamon Press, Oxford, pp.1-18.

Kuzgunkaya, E.H. and Hepbasli, A. (2007a) 'Exergetic performance assessment of a ground-source heat pump drying system', International Journal of Energy Research, Vol. 31, pp.760-777.

Kuzgunkaya, E.H. and Hepbasli, A. (2007b) 'Exergetic evaluation of drying of laurel leaves in a vertical ground-source heat pump drying cabinet', International Journal of Energy Research, Vol. 31, pp.245-258. 
Midilli, A. and Kucuk, H. (2003) 'Energy and exergy analysis of solar drying process of pistachio', Energy, Vol. 28, pp.539-556.

Mujumdar, A.S. (1997) 'Drying fundamentals', in Baker, C.G.J. (Ed.): Industrial Drying of Foods, Chapman \& Hall, London, pp.7-30.

Ozgener, L. (2007) 'Exergoeconomic analysis of small industrial pasta drying systems', Proc. IMechE Part A: J. Power and Energy, Vol. 221, pp.899-906.

Schmidt, E.L., Klöcker, K., Flacke, N. and Steimle, F. (1998) 'Applying the transcritical $\mathrm{CO}_{2}$ process to a drying heat pump', International Journal of Refrigeration, Vol. 21, No. 3, pp.202-211.

Soysal, Y. (2004) 'Microwave drying characteristics of parsley', Biosystems Engineering, Vol. 89, No. 2, pp.167-173.

Soysal, Y., Öztekin, S. and Eren, Ö. (2006) 'Microwave drying of parsley: modelling, kinetics and energy aspects', Biosystem Engineering, Vol. 93, No. 4, pp.403-413.

Syahrul, S., Dincer, I. and Hamdullahpur, F. (2003) 'Thermodynamic modeling of fluidized bed drying of moist particles', International Journal of Thermal Sciences, Vol. 42, pp.691-701.

Syahrul, S., Hamdullahpur, F. and Dincer, I. (2002) 'Exergy analysis of fluidized bed drying of moist particles', Exergy, an International Journal, Vol. 2, pp.87-98.

Van Gool, W. (1997) 'Energy policy: fairly tales and factualities', in Soares, O.D.D., Martins da Cruz, A., Costa Pereira, G., Soares, I.M.R.T. and Reis, A.J.P.S. (Eds.): Innovation and Technology - Strategies and Policies, Kluwer Academic Publishers, Dordrecht, pp.93-105.

Yaghmaee, P. and Durance, T. (2007) 'Efficacy of vacuum microwave drying in microbial decontamination of dried vegetables', Drying Technology, Vol. 25, pp.1109-1114.

\section{Nomenclature}

\begin{tabular}{ll}
\hline$C$ & Specific heat $(\mathrm{kJ} / \mathrm{kg} \mathrm{K})$ \\
$\dot{E}$ & Energy rate $(\mathrm{kW})$ \\
$\dot{E} x$ & Exergy rate $(\mathrm{kW})$ \\
$F$ & Function \\
$h$ & Specific enthalpy $(\mathrm{kJ} / \mathrm{kg})$ \\
$\dot{I} P$ & Improvement potential rate $(\mathrm{kW})$ \\
$\dot{m}$ & Mass flow rate $(\mathrm{kg} / \mathrm{s})$ \\
$M$ & Moisture \\
$P$ & Pressure (bar) \\
$R$ & Ideal gas constant $(\mathrm{kJ} / \mathrm{kgK})$ \\
$R H$ & Relative humidity $(\%)$ \\
$s$ & Specific entropy $(\mathrm{kJ} / \mathrm{kgK})$ \\
$\mathrm{SMER}$ & Specific moisture extraction rate $(\mathrm{kg} / \mathrm{kWh})$ \\
$\mathrm{SMExR}$ & Specific moisture exergetic index $(\mathrm{kg} / \mathrm{kWh})$ \\
$T$ & Temperature $\left({ }^{\circ} \mathrm{C}\right.$ or K) \\
$t$ & Time $($ Min. or s) \\
$V$ & Velocity $(\mathrm{m} / \mathrm{s})$ \\
$U, u$ & Uncertainty \\
$W$ & Weight $(\mathrm{kg})$ \\
$\dot{W}$ & Work rate or power $(\mathrm{kW})$ \\
$z$ & Independent variable \\
\hline
\end{tabular}




\begin{tabular}{ll}
\hline \multicolumn{2}{l}{ Greek letters } \\
$\eta$ & Energetic efficiency (\%) \\
$\varepsilon$ & Exergetic efficiency (\%) \\
$\psi$ & Specific exergy (kJ/kg) \\
$\omega$ & Specific humidity ratio (kg water/kg air) \\
Indices & \\
0 & Dead (reference) state \\
av & Average \\
$b$ & Boundary \\
comp & Compressor \\
$d$ & Dry \\
da & Drying air \\
dest & Destruction \\
elec & Electrical \\
evap & Evaporator \\
$f g$ & Vapourisation \\
$i$ & Initial \\
in & Inflow \\
$m$ & Material \\
mech & Mechanical \\
$p$ & Product \\
out & Outflow \\
$w$ & Water \\
over dot & Quantity per unit time \\
\hline
\end{tabular}

